\title{
Analisis pengaruh kondisi new normal terhadap minat masyarakat dalam berwisata di Kota Malang
}

\author{
Naura Anudya, Farida Rahmawati* \\ Universitas Negeri Malang, Jl. Semarang No. 5 Malang, Jawa Timur, Indonesia \\ *Penulis korespondensi, Surel: farida.rahmawati.fe@um.ac.id
}

Paper received: 5-7-2021; revised: 23-7-2021; accepted: 30-7-2021

\begin{abstract}
In accordance with the direction of the central government, with the enactment of the policy new normal expected to be able to restore the wheels of the economy such as production, distribution and public consumption in the city of Malang. The tourism sector is no exception, which relies heavily on visitors from foreign countries, outside the region and also domestically. Therefore, the purpose of this study is to try to understand how much public interest is and what variables have an effect on traveling in conditions new normal. There are four variables to be studied, namely income, age, health protocols, and expenses for traveling. Data were collected from respondents using a questionnaire, and the sampling technique used by the author was non-probability sampling with purposive sampling type. The number of respondents in this study were 38. The analytical method used was multiple linear regression. The results showed that the condition new normal had a significant effect on people's interest in traveling on the age variable of 0.023 and expenditure for traveling by 0.047 , while the income variable and health protocol had no significant effect.
\end{abstract}

Keywords: Malang City; new normal; interest in traveling

\begin{abstract}
Abstrak
Sesuai dengan arahan pemerintah pusat, dengan diberlakukannya kebijakan new normal diharapkan dapat mengembalikan jalannya roda perekonomian seperti produksi, distribusi dan konsumsi masyarakat di Kota Malang. Tak terkecuali pada sektor pariwisata yang sangat mengandalkan pengunjung dari mancaNegara, luar daerah dan juga domestik. Maka dari itu, tujuan penelitian ini adalah untuk berusaha memahami seberapa besar minat masyarakat dan variabel apa saja yang berpengaruh dalam berwisata pada kondisi new normal. Terdapat empat variabel yang akan diteliti, yaitu pendapatan, usia, protokol kesehatan, dan pengeluaran untuk berwisata. Data dikumpulkan dari responden dengan menggunakan kuesioner, dan teknik pengambilan sampel yang digunakan oleh penulis adalah non-probability sampling dengan jenis purposive sampling. Jumlah responden dalam penelitian ini sebanyak 38. Metode analisis yang digunakan adalah regresi linier berganda. Hasil penelitian menunjukkan bahwa kondisi new normal berpengaruh signifikan terhadap minat masyarakat dalam berwisata pada variabel usia sebesar 0,023 dan pengeluaran untuk berwisata sebesar 0,047 , sedangkan pada variabel pendapatan dan protokol kesehatan tidak berpengaruh signifikan.
\end{abstract}

Kata kunci: Kota Malang; new normal; minat berwisata

\section{Pendahuluan}

Awal mula munculnya pandemi Covid-19 di Indonesia pada bulan Maret 2020 , sektor pariwisata merupakan sektor yang terkena dampak pandemi yang cukup besar, dimana industri pariwisata dan perdagangan harus memberhentikan kegiatan usaha dan merumahkan sebagian besar karyawan. Hal ini dilakukan karena mendukung anjuran pemerintah Indonesia untuk tetap melaksanakan kegiatan bekerja dari rumah dengan istilah work from home selama diberlakukannya Pembatasan Sosial Berskala Besar atau PSBB (Mungkasa, 2020). 
Dengan diberlakukannya PSBB di seluruh Indonesia termasuk Kota Malang memberikan dampak yang cukup signifikan terhadap menurunnya jumlah wisatawan, baik manca Negara, luar kota, maupun domestik. Menurut Kepala Disporapar Kota Malang, Ida Ayu Made Wahyuni membenarkan bahwa wabah Covid-19 dan pemberlakukan kebijakan PSBB berhasil menurunkan jumlah wisatawan di Kota Malang sebesar 66,8 persen, perbandingan ini pada periode tahun 2019 dengan tahun 2020 (Wicaksana, 2021).

Hal ini mengakibatkan sektor-sektor penunjang industri pariwisata seperti hotel, resto, dan juga pedagang atau UMKM merasakan dampaknya secara langsung, dimana mereka terpaksa tutup karena sepinya wisatawan dari luar negeri maupun domestik yang mengunjungi tempat wisata dan membeli oleh-oleh dari UMKM daerah tersebut.

Pada tanggal 5 Juni 2020 telah resmi diberlakukan new normal oleh pemerintah pusat. Era new normal yang dimaksud oleh pemerintah adalah kembali berjalannya roda perekonomian nasional dan daerah (Maharani \& Mahalika, 2020), dimana semua lapisan masyarakat sudah diperbolehkan melakukan kegiatan ekonomi berupa produksi, distribusi, dan konsumsi akan tetapi harus beradaptasi dengan situasi dan kondisi saat ini.

Seperti yang kita ketahui bahwa berwisata merupakan salah satu kegiatan konsumsi, maka dari itu pada kondisi new normal seluruh tempat industri pariwisata mulai menerapkan protokol kesehatan untuk membantu pencegahan penyebaran virus Covid-19 (Widiyanti et al., 2018).

Dengan diterapkannya protokol kesehatan pada setiap industri pariwisata, tanpa terkecuali termasuk rumah makan (restoran cepat saji), penginapan, bahkan UMKM. Hal ini diharapkan dapat menstimulasi masyarakat dalam melakukan kegiatan berwisata di kondisi new normal (Bascha, U. F., Reindrawati, D. Y., Witaningrum, A. M., \& Sumardiko, D. S., 2020). Dengan mempertimbangkan protokol kesehatan yang diterapkan ketat dan diberlakukannya pembatasan jumlah pengunjung.

Berdasarkan uraian diatas, penelitian ini bertujuan untuk mengetahui minat masyarakat dalam berwisata di Kota Malang selama kondisi new normal. Selain protokol kesehatan, apakah pendapatan selama kondisi new normal, usia para wisatawan, dan pengeluaran untuk berwisata dapat mempengaruhi minat masyarakat dalam melakukan kegiatan wisata dalam kondisi new normal.

\subsection{KAJIAN PUSTAKA}

\subsubsection{Sektor Periwisata}

Sektor pariwisata dapat disebut sebagai industri pariwisata, yang dapat diartikan sebagai sekelompok kawasan usaha yang menghasilkan berbagai jenis barang dan jasa, yang penting bagi sekelompok pelancong. Setiap produk, baik yang terlihat secara fisik atau hanya tersedia online, adalah untuk memenuhi kebutuhan manusia dan harus dievaluasi sebagai produk industri. Dimana pariwisata adalah salah satu industri besar yang mendorong pertumbuhan ekonomi tercepat di dunia (Jumadi, 2016).

Sedangkan menurut Undang-Undang Kepariwisataan Republik Indonesia No 9 Tahun 1990, keadaan alam, flora dan fauna, peninggalan purbakala, peninggalan sejarah, serta seni 
dan budaya yang dimiliki oleh bangsa Indonesia merupakan sumber daya dan modal. Hal ini sangat penting untuk pengembangan dan promosi industri pariwisata; yang kemudian diubah menjadi Undang-Undang Kepariwisataan No. 10 tahun 2009, mengingat industri pariwisata sebagai seperangkat perusahaan pariwisata yang saling berkaitan untuk menghasilkan barang dan/atau jasa guna memenuhi kebutuhan wisatawan dalam penyelenggaraan permintaan pariwisata.

\subsubsection{Unsur Industri Pariwisata}

Adapun meliputi unsur-unsur dalam industri pariwisata yaitu: (1) Restoran. (2) Penginapan. (3) Pelayanan perjalanan. (4) Transportasi. (5) Pengembangan daerah tujuan wisata. (6) Fasilitas rekreasi. (7) Atraksi wisata (Badan Pusat Statistik, 2021).

\subsubsection{Pariwisata dan Kunjungan Wisatawan}

(Priambodo, 2015) Istilah pariwisata sering disamakan dengan tourism, yang ditafsirkan sebagai kegiatan untuk bepergian dengan tujuan untuk meningkatkan kepuasan dan dilakukan secara sukacita.

Sedangkan menurut Undang-Undang Kepariwisataan Republik Indonesia No.10 Tahun 2009 pariwisata adalah berbagai kegiatan pariwisata yang didukung oleh berbagai fasilitas dan pelayanan yang diberikan oleh masyarakat, pengusaha, pemerintah, dan pemerintah daerah.

Pariwisata adalah setiap kegiatan multidimensi dan multidisiplin yang berkaitan dengan pariwisata, yang mencerminkan kebutuhan setiap orang dan Negara, serta interaksi antar wisatawan dan masyarakat lokal, wisatawan, pengusaha, pemerintah dan pemerintah daerah. Jadi wisatawan adalah orang yang melakukan perjalanan untuk kegiatan wisata, apapun tujuannya, yang terpenting bepergian bukan untuk tinggal di daerah tersebut atau mencari nafkah.

\subsubsection{Minat Berwisata}

Minat berwisata atau berkunjung dianggap sama dengan minat membeli, menurut Depdikbud minat merupakan kecenderungan, gairah, keinginan yang tinggi dan berasal dari hati terhadap sesuatu (Sinaga et al., 2020). Dimana minat merupakan kecenderungan seseorang untuk mengenang dan melihat beberapa aktivitas yang dilakukan seseorang. Minat berwisata di era new normal adalah keinginan untuk melakukan wisata di tengah pandemi dengan tetap melakukan penerapan protokol kesehatan di seluruh industri pariwisata.

Dimana minat membeli memiliki 4 indikator yaitu: (1) Transaksional. (2) Referensial. (3) Preferensial. (4) Eksploratif

\subsubsection{Pendemi Covid-19}

Pandemi memiliki definisi sebagai persebaran penyakit yang terjadi secara global di seluruh dunia. World Health Organization (WHO) menyatakan bahwa munculnya Covid-19 sebagai pandemi (Purba, 2021). Sedangkan pandemi Covid-19 adalah persebaran virus secara global dengan nama Covid-19 atau dapat disebut juga corona virus yang berdampak buruk pada dimensi manusia dan sosial. 


\subsubsection{Era New Normal}

New normal dapat digunakan dalam berbagai aktivitas yang berkaitan dengan suatu perbedaan yang sebelumnya dianggap tidak normal atau tidak umum dilakukan (Rahmadiyanti et al., 2020). New normal atau normal baru merupakan tatanan hidup baru yang mengharuskan kita untuk hidup berdampingan dengan Covid-19. Pemerintah menyebut hal ini sebagai 'Penyesuaian PSBB', dimana standar dan prosedur sedang dikembangkan, dan bagaimana penyesuaian PSBB akan diterapkan.

Hal ini perlu disadari juga bahwa tatanan kehidupan normal baru bukan hanya manusia hidup berdampingan dengan Covid-19, tetapi tatanan kehidupan baru juga merupakan kehidupan manusia yang selalu menghadapi ancaman Covid-19 (Muhyiddin, M, 2020).

\section{Metode}

Data yang peneliti butuhkan adalah data primer dan data sekunder. Data primer digunakan untuk menguji data dari para responden, sedangkan data sekunder merupakan data yang diperoleh dari hasil regresi linier berganda yang digunakan untuk memperoleh data teoritis dan pendukung. Instrumen pengumpulan data yang digunakan adalah kuesioner atau angket. Jenis yang digunakan adalah kuesioner online atau kuesioner yang diisi melalui Google form. Dengan menggunakan kuesioner online penulis dapat mengumpulkan data dalam jumlah besar pada waktu yang bersamaan.

Teknik sampling yang digunakan penulis adalah non-probability sampling dengan jenis purposive sampling. Purposive sampling adalah metode yang digunakan dengan menentukan kriteria-kriteria tertentu (Sugiyono, 2013). Jumlah wisatawan yang pernah berkunjung ke Kota Malang selama kondisi new normal sebanyak 42 responden. Jumlah sampel responden dalam penelitian ini diperoleh menggunakan rumus Slovin, yaitu:

$$
\mathrm{n}=\frac{N}{1+N(e)^{2}}
$$

Keterangan:

$\mathrm{n} \quad=$ Sampel

$\mathrm{N} \quad=$ Populasi

e $\quad=$ Jumlah persen ketidaktelitian pengambilan sampel yang dapat ditolerir (5\%)

Jika dimasukkan dalam rumus Slovin menjadi:

$$
\begin{aligned}
& \mathrm{n}=\frac{42}{1+42(0,05)^{2}} \\
& \mathrm{n}=38
\end{aligned}
$$

Maka sampel pada penelitian ini sebanyak 38 responden yang datanya diolah menggunakan metode regresi linier berganda kemudian secara deskriptif menjelaskan dan menguraikan hasil jawaban. 


\subsection{Uji Asumsi Klasik}

Metode Ordinary Least Squares (OLS) merupakan model regresi sederhana yang digunakan untuk melakukan regresi linier dalam suatu model. Metode tersebut berusaha meminimalkan penyimpanan hasil perhitungan regresi terhadap kondisi aktual yang bertujuan untuk memastikan validitas data yang digunakan secara teori tidak bias (Gujarati \& Porter, 2015). Untuk menghindari hasil model regresi tidak bias atau BLUE (Best Linear Unbiased Estimator) maka model harus memenuhi asumsi klasik. Dalam uji asumsi klasik harus dipenuhi dalam model regresi yang terdiri dari:

\subsubsection{Uji Normalitas}

Tujuan dilakukannya Uji normalitas adalah untuk menguji apakah variabel pengganggu atau residual berdistribusi normal, karena asumsi yang harus dipenuhi adalah nilai residual mengikuti distribusi normal (Ghozali Imam, 2016).

\subsubsection{Uji Multikolinearitas}

Tujuan dilakukannya uji multikolinearitas untuk menguji adanya korelasi antar variabel independen. Asumsi yang harus dipenuhi adalah tidak adanya korelasi antar variabel independen. Jika model regresi memiliki masalah multikolinearitas, sulit untuk melihat pengaruh variabel penjelas terhadap variabel deskriptif (Ghozali Imam, 2016).

\subsubsection{Uji Heterokedastisitas}

Tujuan dilakukannya uji heterokedastisitas adalah untuk menguji apakah terdapat varians residual yang tidak sama dari satu pengamat ke pengamat lainnya dalam model regresi. (Ghozali Imam, 2016).

\subsection{Uji Hipotesis}

Gujarati dan Porter (2015) menyatakan bahwa uji hipotesis atau uji signifikansi bertujuan untuk menguji kebenaran atau kesalahan dari hasil hipotesis nol dari sampel. Tingkat signifikansi (alpha) yang digunakan dalam penelitian ini adalah 5\%. Uji hipotesis dalam penelitian ini menggunakan 3 uji yaitu:

\subsubsection{Uji t}

Uji t digunakan untuk mengetahui apakah setiap variabel independen (protokol kesehatan, usia, pendapatan masyarakat dan pengeluaran untuk berwisata) memiliki pengaruh terhadap variabel dependen (minat berwisata) di Kota Malang.

\subsubsection{Uji F}

Uji F bertujuan untuk mengetahui signifikansi variabel bebas yang dimasukkan dalam model mempunyai pengaruh secara bersama-sama (simultan) terhadap variabel terikat. 


\subsubsection{Uji Determinasi (R-Square)}

Uji determinasi digunakan untuk mengetahui seberapa besar tingkat kemampuan variabel independen dalam menerangkan variabel dependen pada model.

\section{Hasil dan Pembahasan}

Hasil dari penelitian ini menunjukkan terdapat 38 responden dengan karakteristik pada variabel pendapatan paling banyak memiliki pendapatan sebesar Rp. 1.200.000-3.500.000, dengan total pengeluaran untuk berwisata paling banyak sebesar Rp. 150.000-300.000, responden terbanyak pada usia 21-22, dan nilai untuk penerapan protokol kesehatan paling banyak pada skala 4 .

\subsection{Hasil Uji Asumsi Klasik}

\subsubsection{Uji Normalitas}

Tabel 1. Hasil Uji Normalitas

\begin{tabular}{lll}
\hline \multicolumn{1}{c}{ Variabel } & $\mathbf{P}>/ \mathbf{t} /$ & \multicolumn{1}{c}{ Keterangan } \\
\hline $\begin{array}{l}\text { Protokol kesehatan } \\
\text { Usia }\end{array}$ & 0,997 & Tidak signifikan \\
$\begin{array}{l}\text { Pendapatan selama } \\
\text { new normal }\end{array}$ & 0,023 & Signifikan \\
$\begin{array}{l}\text { Pengeluaran untuk } \\
\text { berwisata }\end{array}$ & 0,955 & Tidak signifikan \\
\hline
\end{tabular}

Sumber: Data diolah dengan STATA 2020

Pada tabel 1 menunjukkan nilai signifikansi pada variabel usia dan pengeluaran untuk berwisata masing-masing bernilai 0,023 dan 0,047 karena nilainya kurang dari alpha atau 0,05.

\subsubsection{Uji Multikolinearitas}

Tabel 2. Hasil Uji Multikolinieritas

\begin{tabular}{lll}
\hline Variabel & VIF & $\mathbf{1 / V I F}$ \\
\hline Y & 2,69 & 0,371494 \\
C & 2,19 & 0,456055 \\
Usia & 1,22 & 0,818877 \\
Prokes & 1,22 & 0,820696 \\
Mean VIF & 1,83 & \\
\hline
\end{tabular}

Sumber: Data diolah dengan STATA 2020

Multikolinearitas merupakan terdapatnya hubungan atau korelasi kuat antar variabel independen VIF > 10 sehingga dapat dikatakan bahwa model regresi linier berganda tidak memiliki multikolinearitas. Hasil uji multikolinearitas menunjukkan $1.83>10$ sehingga tidak ada hubungan antara variabel independen dalam model.

\subsubsection{Uji Heterokedastisitas}

Tabel 3. Hasil Uji Heterokedastisitas

\begin{tabular}{ll}
\hline chi2(1) & 0,07 \\
Prob $>$ chi2 & 0,7943 \\
\hline
\end{tabular}

Sumber: Data diolah dengan STATA 2020 
Pada uji heterokedastisitas tidak terjadi gejala heterokedastisitas (nonheterokedastisitas) bila nilai $\mathrm{P}$ value dari "prob $>c h i^{2 "}>0,05$. Hasil uji heterokedastisitas menunjukkan sebesar 0,7943 >0,05 maka tidak terjadi heterokedastisitas (nonheterokedastisitas), varian dari error term konstan.

\subsection{Uji Hipotesis}

\subsubsection{Uji t}

Berdasarkan hasil dari analisis regresi linier berganda di atas, maka dapat dibuat persamaan berganda:

\section{$Y=2.662958+.0009987 X 1+.0706091 X 2+1.08 \mathrm{e}-08 \times 3+(-2.16 \mathrm{e}-06) X 4+e$}

Variabel independen dikatakan signifikan jika $t$ hitung $>t$ tabel. Untuk hasil data penelitian diatas: (1). Dari persamaan regresi berganda diatas terlihat nilai konstanta sebesar 2.662958, yang mana menunjukan bahwa tanpa adapun variabel independen berupa protokol kesehatan, usia, pendapatan selama new normal, dan konsumsi berwisata terhadap minat masyarakat dalam berwisata adalah positif sebesar 2.662958. (2). Ketika penerapan protokol kesehatan naik sebesar satuan-satuan, maka minat masyarakat dalam berwisata di Kota Malang selama kondisi new normal naik sebesar 0.0009987 secara rata-rata dengan asumsi variabel lain tetap. (3). Ketika usia responden naik rata-rata sebesar 1 tahun, maka minat masyarakat dalam berwisata di Kota Malang selama kondisi new normal naik sebesar . 0706091 secara rata-rata dengan asumsi variabel lain tetap. (4). Ketika y (pendapatan) naik rata-rata seribu rupiah, maka minat masyarakat dalam berwisata di Kota Malang selama kondisi new normal naik sebesar 1.08e-08 secara rata-rata dengan asumsi variabel lain tetap. (5). Ketika c (pengeluaran untuk berwisata) naik rata-rata seribu rupiah, maka minat masyarakat dalam berwisata di Kota Malang selama kondisi new normal turun sebesar -2.16e06 secara rata-rata dengan asumsi variabel lain tetap.

\subsubsection{Uji F}

Berdasarkan hasil dari uji F terhadap variabel diperoleh nilai Prob $>F$ sebesar 0,0382. Maka dilihat dari hasil Prob $>$ F sebesar 0,0382 < 0,05 sehingga secara simultan rata-rata protokol kesehatan, usia responden, pendapatan saat new normal, dan pengeluaran untuk berwisata berpengaruh signifikan terhadap minat berwisata di Kota Malang.

\subsubsection{Uji Determinasi (Uji R-Square)}

Nilai R-square diperoleh sebesar 0,2580 yang artinya kemampuan protokol kesehatan, usia responden, pendapatan saat new normal, dan pengeluaran untuk berwisata dalam menjelaskan minat berwisata di Kota Malang sebesar 25,80\% dan sisanya dapat disempurnakan oleh variabel lain diluar model.

Dari keempat variabel independen yang mempengaruhi minat masyarakat dalam berwisata di Kota Malang selama kondisi new normal adalah usia dan pengeluaran untuk berwisata dengan hasil pada regresi linier berganda angka dua variabel tersebut kurang dari alpha $(0,05)$. 
Hal ini dikarenakan mayoritas responden berusia 21-22 yang mana dalam usia tersebut memiliki minat berwisata tinggi saat kondisi new normal, akibat merasa bosan karena terlalu lama berada di dalam rumah. Hal ini mengindikasikan bahwa usia responden sangat mempengaruhi minat berwisata dan juga total pengeluaran responden saat berwisata berpengaruh karena seperti yang telah disebutkan dalam teori konsumsi Keynesian apabila semakin tinggi pendapatan seseorang maka semakin tinggi juga jumlah pengeluarannya.

\section{Simpulan}

Minat masyarakat dalam berwisata di Kota Malang selama kondisi new normal cukup baik, dilihat dari tingginya minat masyarakat dalam berwisata. Hal ini tidak lepas dari faktorfaktor yang mempengaruhi seperti variabel protokol kesehatan, pendapatan, usia dan total pengeluaran yang dihabiskan untuk melakukan wisata. Dimana faktor-faktor yang mempengaruhi minat masyarakat dalam berwisata di Kota Malang selama kondisi new normal secara signifikan adalah variabel umur dan pengeluaran untuk berwisata. Sedangkan variabel protokol kesehatan dan pendapat merupakan variabel yang tidak mempengaruhi minat masyarakat dalam berwisata di Kota Malang selama kondisi new normal secara signifikan.

\section{Daftar Rujukan}

Badan Pusat Statistik. (2021). Pariwisata. https://www.bps.go.id/subject/16/pariwisata.html

Bascha, U. F., Reindrawati, D. Y., Witaningrum, A. M., \& Sumardiko, D. S. (2020). Dampak Pandemi COVID-19 Terhadap Minat Masyarakat dalam Berwisata dan Sosialisasi Penerapan Protokol New Normal Saat Berwisata. Jurnal Abdidas, 1(6), 560-570.

Ghozali Imam. (2016). APLIKASI ANALISIS MULTIVARIETE DENGAN PROGRAM IBM SPSS 23 (VIII). Aplikasi Analisis Multivariate Dengan Program IBM SPSS23. Edisi 9.Semarang: Badan Penerbit Universitas Diponegoro., 3(April), 2010-2014.

Gujarati, D. N., \& Porter, D. C. (2015). Dasar-dasar Ekonometrika (M. Muluk (ed.); 5th ed.). Penerbit Selemba Empat.

Jumadi, J. (2016). Pengaruh Pemasaran Internal dan Kualitas Layanan Internal Terhadap Kepuasan Pelanggan Internal (Studi Pada Industri Kepariwisataan di Daerah Istimewa Yogyakarta). Jurnal Ekonomi Dan Bisnis, 17(3), 17. https://doi.org/10.24914/jeb.v17i3.285

Maharani, A., \& Mahalika, F. (2020). New Normal Tourism Sebagai Pendukung Ketahanan Ekonomi Nasional Pada Masa Pandemi ( New Normal Tourism As a Support of National Economic Resistance in the Pandemic Period ). Jurnal Kajian LEMHANNAS RI, $8, \quad 14$. http://jurnal.lemhannas.go.id/index.php/jkl/article/view/87

Mungkasa, O. (2020). Bekerja dari Rumah (Working From Home/WFH): Menuju Tatanan Baru Era Pandemi COVID 19. Jurnal Perencanaan Pembangunan: The Indonesian Journal of Development Planning, 4(2), 126-150. https://doi.org/10.36574/jpp.v4i2.119

Muhyiddin, M. (2020). Covid-19, New Normal, dan Perencanaan Pembangunan di Indonesia. Jurnal Perencanaan Pembangunan: The Indonesian Journal of Development Planning, 4(2), 240-252.

Purba, I. P. (2021). IMPLEMENTASI UNDANG-UNDANG NOMOR 6 TAHUN 2018 TENTANGKEKARANTINAAN KESEHATAN DI JAWA TIMUR MENGHADAPI PANDEMI COVID 19. Jurnal Pahlawan, 4(1), 1-11.

Rahmadiyanti, T., Pusparini, S. B., Vaddhanti, M. D., \& Arnevilia, A. D. (2020). Penerapan Kebiasaan Baru Dalam Pencegahan Persebaran Pandemi Covid-19 Pada Masyarakat Melalui Media Sosial. Lapkknunnes, 2. https://kkn.unnes.ac.id/lapkknunnes/32004_1805202006_6_Desa_20200927_111702.pdf

Sinaga, O. S., Candra, V., \& Putri, D. E. (2020, September). PERAN FASILITAS DAN HARGA UNTUK MENDORONG MINAT BERKUNJUNG DALAM SITUASI COVID 19 (STUDI PADA TAMAN HEWAN KOTA PEMATANGSIANTAR). In Seminar Nasional Manajemen, Ekonomi dan Akuntansi (Vol. 5, No. 1, pp. 431438).

Sugiyono. (2013). Metode Penelitian Pendidikan: Pendekatan Kuantitatif \& Kualitatif, dan R\&D.

Wicaksana, Y. S. W. (2021). Kunjungan Wisata Kota Malang 2020 Jeblok Sampai 66,8 Persen. 1 Februari. https://kabarmalang.com/18013/kunjungan-wisata-kota-malang-2020-jeblok-sampai-668-persen 
Jurnal Ekonomi, Bisnis dan Pendidikan, 1(7), 2021, 661-669

Widiyanti, F., Ananta, H., Isnaeni, N., Semarang, U. N., Blado, K., Wisata, P. K., \& Pengunjung, P. (2018). Pengaruh Pandemi Covid-19 Terhadap Wisata Religi. 